II

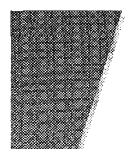

\title{
身近になった都市水害
}

\section{Urban Flood Disaster Occurred in Daily Life Area}
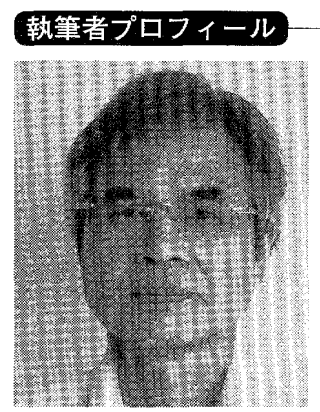

中根 和郎

Kazurou NAKANE
○1973 年名古屋工大第二部電気工学科卒, 同 年旧国立防災センターに入所, 水害, 水文学, リモートセンシングなどの研究に 30 年以上 従事，この間，旧建設省工事事務所にて 3 年 間水文観測および洪水予報に従事

(9研究・専門テーマは，洪水災害研究で，リア ルタイム浸水被害危険度予測に取り組んでい る

(9) (独) 防災科学技術研究所 水・土砂防災研 究部 総括主任研究員

（テ305-0006＼cjkstart茨城県つくば市天王台 3-1） E-mail : nakane@bosai.go.jp)

\section{1. はじめに}

798 ページの「時とともに変貌する水害」で述べたよう に，多くの都市は潜在的に水害に弱い低平地にあり，ダム や河川などの治水施設によって守られている，大河川は 100 ～ 200 年に 1 度の年超過確率の大雨でも安全に雨水を 排水できるように計画・施工されているが，中小河川は， 社会的経済的に重要な都市河川で50 100 年, 一般河川 では $10 \sim 50$ 年に 1 度の年超過確率の大雨まで安全に排水 できるように計画・施工されている。つまり，中小河川沿 い低地は一生のうち 1 度以上は水害に遭遇する可能性が高 いことになる。主要都市の下水道区域ではさらに状況が悪 くなっている。図 1 に主要都市の下水道区域における計画 雨水排水能力を示す。この図からもわかるように, 主要都 市でさ之, 時間雨量 $30 \sim 60 \mathrm{~mm}$ 以上の豪雨が降ると内水

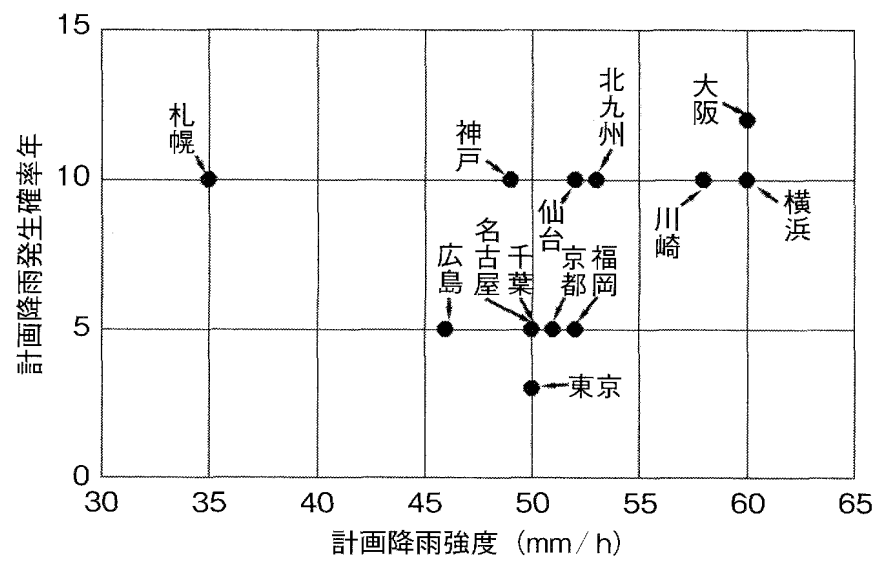

図 1 都市下水道雨水排水計画 降雨強度とその発生確率 〔国土交通省河川局資料（2005）より作成〕

染濫が発生する恐れがある。しかも，それらは $3 〜 15$ 年 に 1 度の年超過確率で起こる. 図 2 に, 水害の誘引となる 豪雨の発生状況を示した。アメダスの 1300 箇所の雨量観 測点で時間雨量 $70 \mathrm{~mm}$ を超えた豪雨の発生回数は年間 20 〜 70 回に達している，年によっては 1999 年のように，時 間雨量 $100 \mathrm{~mm}$ を超える記録的な豪雨が 10 回も起こって いる. 2008 年も，石川県金沢市 $(138 \mathrm{~mm})$, 愛知県阔崎市 $(146.5 \mathrm{~mm})$, 一宮市 $(120 \mathrm{~mm})$, 千葉県我孫子市 $(105 \mathrm{~mm})$ などで時間雨量 $100 \mathrm{~mm}$ を超す豪雨が降り，中小河川が汇 濫し，大きな浸水被害が発生した，潜在的に水害に弱い低 平地に暮らす知恵として, 浸水を想定した被害軽減策を立 てておくことがますます大切になっている。ここでは史上 最大の豪雨を記録した 1982 年 7 月の長崎豪雨災害で, 長 崎市内が $0.5 \sim 2.0 \mathrm{~m}$ 浸水し，そこで何が起こったかを述 べるとともに，近年起こっている都市水害から身近に潜む 水害の危険性について述べる。 また，降雨によって起こる 浸水筒所を最先端のレーダ雨量情報を活用して, リアルタ イムに予測し，直前の浸水対策に役立てる取り組みについ て紹介寸る。

\section{2. 長崎豪雨災害}

1957 年 7 月の諫早水害に匹敵する豪雨災害が 1982 年 7 月に諫早市西側の長崎市で起こった。図 3 にそのときの日 雨量分布を示吉。西彼杵半島中央部加長崎市の狭い範囲 （約 $60 \mathrm{~km} \times 30 \mathrm{~km}$ ）に日雨量 $400 \mathrm{~mm}$ を超える大雨がもた らされた。長崎市北部の長与町では最大時間雨量 $187 \mathrm{~mm}$ という観測史上最大の豪雨を記録した ${ }^{(1)(2)}$ ，長崎県下で山 崩れ・崖崩れ 4457 箇所, 83 渓流で土石流が発生した。長 崎市内や東長崎地区を流れる浦上川，中島川，八郎川など の中小河川は流域の大半が豪雨域に覆われ，川の水位が急 上昇し，激しい洪水氾濫が起こった，河川沿いの谷底平野 が濁流に襲われ，低い所は $2 \mathrm{~m}$ 以上浸水した。汇濫流の流 れの速い場所では多くの車が押し流された，被害は九州か

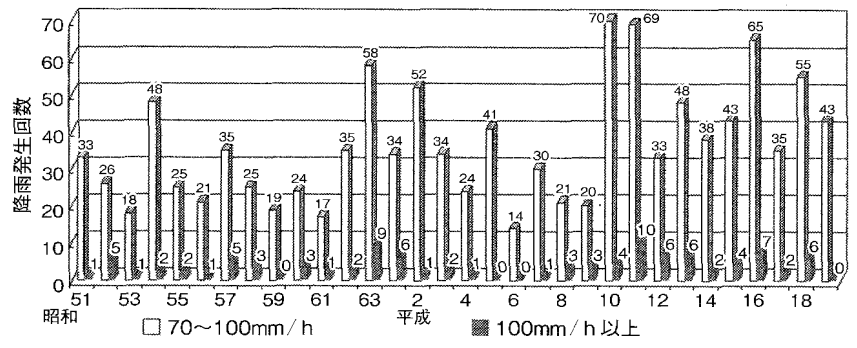

図 2 アメダス 1300 地点における近年の豪雨発生回数 〔北本朝展（国立情報研究所）資料より作成〕 


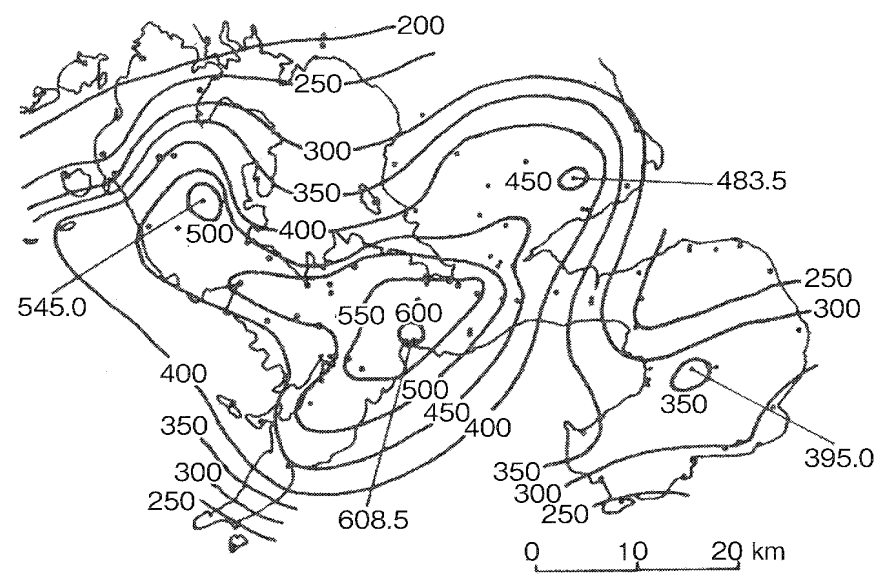

図 3 長崎豪雨日雨量分布（23 日 9 時～24 日 9 時） [荒尾公雄 (1982) 上り引用]

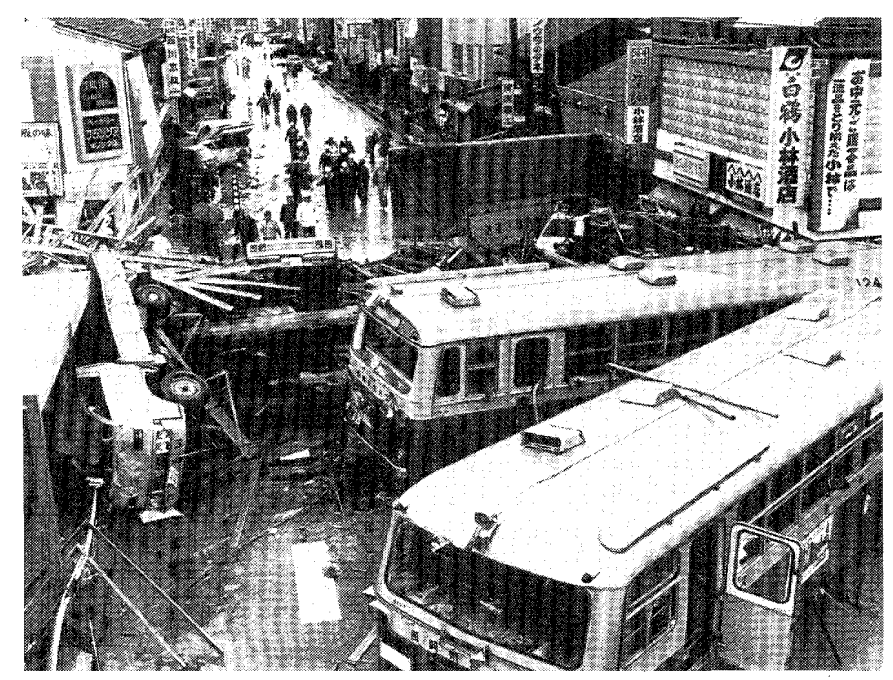

図 5 東長崎市矢上町国道において 67 人を乗せた大型バス 2 台の流出

流出した路線バス・自動車・流木，矢上町東公民館前，道路上約 $1.95 \mathrm{~m}$ 浸水. 1982 年 7 月 24 日撮影. 〔提供：長崎新聞社〕

ら中国地方西部の広い範囲に及んだ。とくに，長崎県下に 被害が集中し, 同県で死者・行方不明者数は 299 人，家屋 の流失・全壊半壊は 1127 棟に達した。死者の大半は土石 流や山崩机・崖崩れによるもので, 家屋が流失, 倒壊, 埋 没し， 262 人が死亡した。洪水汇濫による死者も 37 人に 達し，そのうち，11 人が車の水没や車の川への流失で亡 くなった (2)(4). 図 4 に長崎市の長崎本線長与駅に抢ける豪 雨時の 10 分間雨量の時間変化を示す。

23 日 19 時ごろから豪雨となり, 激しい雨は深夜まで続 いた。長崎市内では 19 時ごろから浸水が起こり始め, 帰 宅時間带の道路は車で混雑していた。雨が滝のように降り 出すと, 車は路上に数珠つなざになって立ち往生し始めた。 普通車の排気口の高さは約 $25 \sim 30 \mathrm{~cm}$ であり、ここから 水が入るとエンジンが止まる，道路が $40 \mathrm{~cm}$ 冠水している ところでの走行実験では，車のギアをローに入れ，排気口 から水が入らないように空ぶかししゆっくり走行すれば通 れないことはないようであるが，かなり運転技術がいる。 車はドアステップ上約 $10 \sim 20 \mathrm{~cm}$ （路面上 $40 \sim 50 \mathrm{~cm}$ ）冠 水すると浮き始め，濁流に押し流されるようになる。さう にドアの半分まで（路面上 $80 \sim 90 \mathrm{~cm}$ ）冠水するとドアが

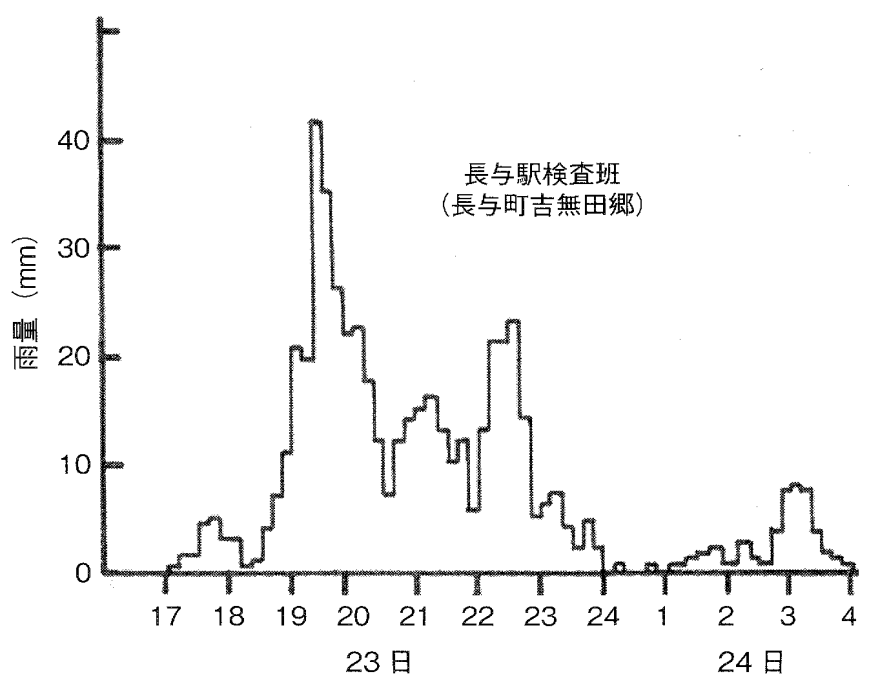

図 4 長崎豪雨時の長崎本線長与駅における 10 分間雨量の 時間変化

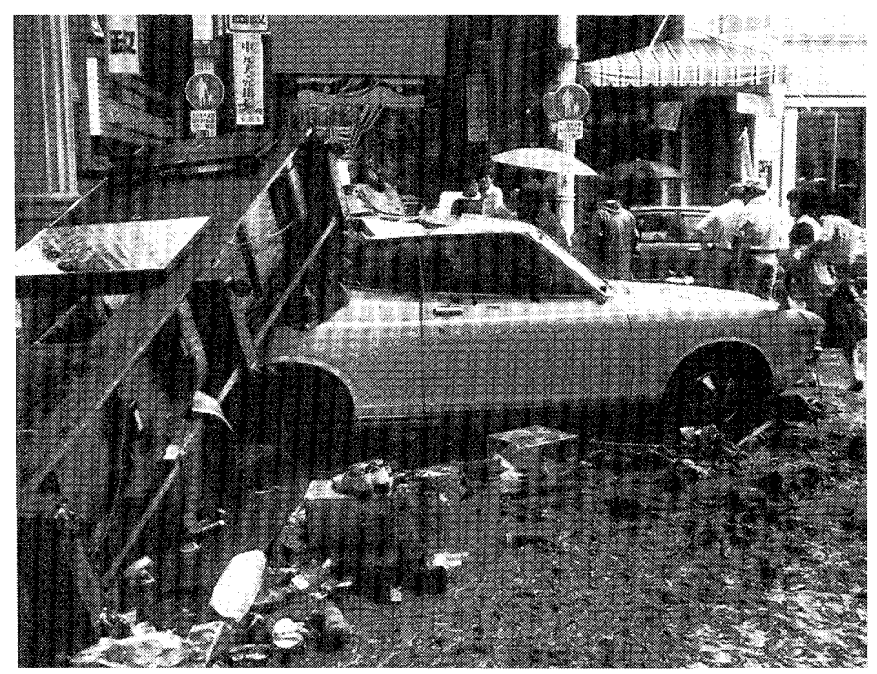

図 6 長崎市浜の町アーケード街での車の流出

1982 年 7 月 24 日長崎新聞夕刊, 流れてきた乗用車に商店のショーケー スが倒れ，付近には靴などの商品が散乱。まるで戦場のようなさんた んたる光景 $=24$ 日午前 7 時 30 分ごろ, 長崎市浜町アーケード街で写す.

[提供：長崎新聞社]

水圧で開きにくくなる(5)。やっかいなことに，車の電気系 統が冠水守るとバッテリーの機能低下やショートが起こ り,パワーウインドの䆔は動かせなくなる。当時, 車に乗っ たまま流された人は少なくなかったのではと思われる。

大型バスも道路が $150 \mathrm{~cm}$ 以上冠水すると浮き始める. 八郎川の氾濫で東長崎地区の矢上町の国道で立ち往生して いた大型バス 2 台が乗客 67 人を乗せたまま流された（図 5）、幸いバスは歩道橋に引っかかり止まった，その後，金 づちで空ガラスを割って，水を車内に引き大れ，バスの流 失を防いた，乗客を救助するため，近くの公民館のカーテ ンをはがして，つなぎ合わせてロープを作り，それを歩道 橋からつるした，乗客はバスの屋根からこのロープを上っ て歩道橋に無事避難することができた。多くの地下室が浸 水した。ビルや病院の多くは地下室に受電・配電設備, 非 常用自家発電機, 空調, ボイラなどの重量な設備を置いて いる，それらが冠水し，ビルや病院の機能が麻瘏した，浸 水による停電で, 非常用自家発電機が自動的に作動し, 地 下室が漏電状態になり，近づくのが危険になる事態も起 こった，そのほか，水压でドアが開かなくなる，停電が長 引き，地下室に入った濁水を排水するのに時間がかかり， 


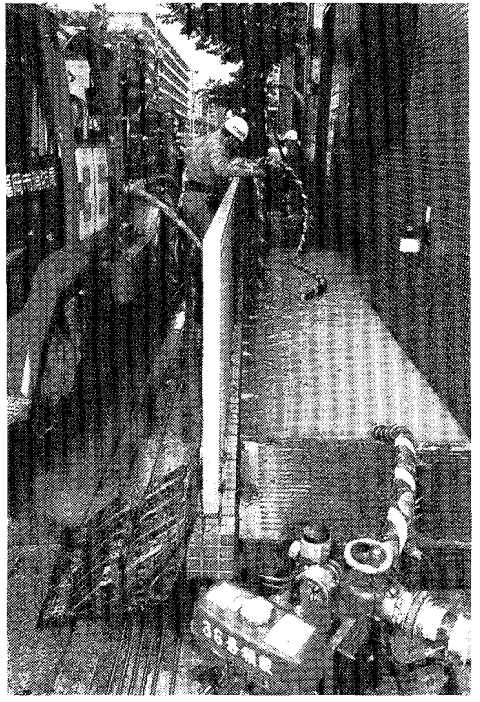

図 71999 年 6 月 29 日福岡市博多東のビル 地下 1 階が水没し，女性従業員 1 名死亡

〔提供：朝日新聞社〕

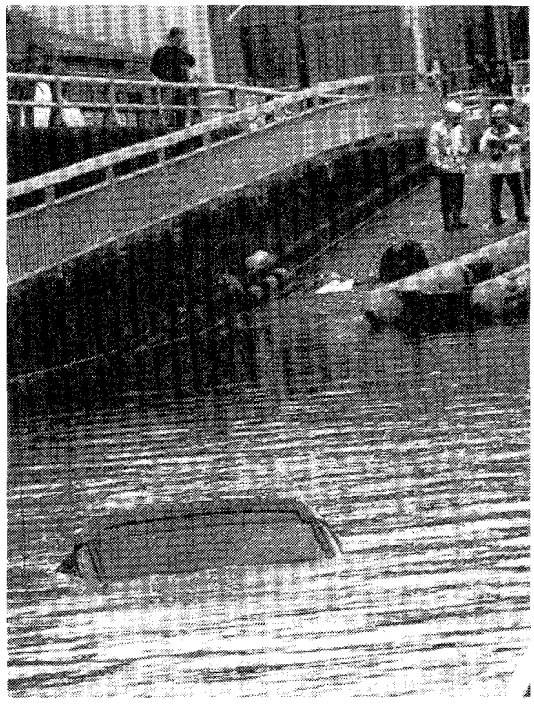

図8 2004 年 11 月 12 日静岡県浜松市の JR 線路を潜る道路 のアンダパスが冠水, 女性（69 歳）が乗った車が進入し て死亡 (2004 年 11 月 12 日朝日新聞).

〔提供：朝日新聞社〕
ビルや病院の機能回復が遅れるところもあった。

地表でもさまざまなことが起こった。マンホールの蓋が 飛び，濁水が激しく噴出した，流れの速い道路では自動販 売機や車などいろんなものが流れ，危険な状態になった(図 6) (7). 水道やガス管が川を横断しているところで, 折れ曲 がったり，流失し，漏水やガス漏れが発生した。あちこち で人が水路に流され死亡した．郊外を走行するバスは孤立 状態になった。 バスは運行計画に従って走行することが義 務づけられており，不安を感じた運転手は会社に連絡を取 り，指示を得ようとするが電話線の切断や電話の輻範で連 絡が取れず，周囲の状況が全くわからず路上に待機した。 中には待機しているバスに土石流が押し寄せるところも あった。市内電話も市外電話も輻輳した。 23 日 20 時ごろ から浸水が激しくなり，帰宅途中の人から自宅への連絡， 市民から 119 番や 110 番への被害通報，避難問い合わせ， 救助要請などの電話が殺到し，市内電話はつながりにくく なり，輻軼した。こうなると，電話は役場，消防署，警察 署などにも殺到するようになった。さらに，21 時 30 分ご ろからテレビやラジオで災害情報や安否情報が放送され始 めると, 安否の確認と救助の依頼が各放送局にも殺到し, 市外電話も輻輳し始め，なかなかつながらなくなった。

\section{3. 近年の都市水害}

前項で述べたように都市下水道区域の計画排水能力を超 える豪雨が毎年のように各地で降り，高知（1998 年 9 月， $126 \mathrm{~mm} / \mathrm{h}$ ), 福岡 (1999 年 6 月, $79.5 \mathrm{~mm} / \mathrm{h})$, 名古屋 $(2000$ 年 9 月, $114 \mathrm{~mm} / \mathrm{h})$, 福井 $(2004$ 年 7 月, $96 \mathrm{~mm} / \mathrm{h})$, 東京 $(2005$ 年 9 月, $112 \mathrm{~mm} / \mathrm{h})$ ，金沢 $(2008$ 年 7 月, $138 \mathrm{~mm} / \mathrm{h})$ ，岡崎 （2008 年 8 月， $146.5 \mathrm{~mm} / \mathrm{h}$ ）などで市街地が浸水する被害 が発生した。福岡や東京では地下窒が水没し， 2 人がしく なった（図 7)。一般に住宅の地下室は容積が小さく，道 路から氾濫水が流れ达むと十数分で天井まで冠水する非常 に危険な場所となる。道路は網の目のように張り巡らされ ており，多くの谷を横断している。道路が湿潤な谷を横断 する際に50〜80 cm 盛り土されることが多い。このよう な谷地形のところに，排水能力を超える豪雨が降ると内水
氾濫が起き,盛り土道路の上流側が一時的に深く湛水する， そういう場所に，止水板取り付けなどの浸水対策を行って いない地下室や地下街の入り口があると汇濫水は容易に地 下空間へ流れ込む，東京都新宿区で地下室が水没し死者が 出た場所は盛り土道路の上流側にあった。

交通渋滞を緩和するため, 主要道路や鉄道は多くの一般 道路と立体交差するようになった。このような道路のアン ダパス部は叫地になっており，浸水しやすく，排水ポンプ や雨水排水管が敷設されている。しかし，排水能力を超え る豪雨が降ると凹地は一時的に染く冠水し，多くの車が進 入して水没亦事故が起こっている．大部分の人は自力で 避難したり，救助されたりして助かっているが，中には悪 い条件が重なって, 死亡する事故が福岡市（1999 年6月）, 浜松市（2004 年 11 月，図 8)，鹿沼市（2008 年 8 月）で 起こっている.

河川の上流には夕゙ムがあり，普段は水が蓄えられるため その下流は水量が少なく, 砂利の中州ができて, 絶好のキャ ンプ場やつり場となっている，夏の行楽シーズンには川遊 びで賑わうが，中には短い休暇を利用して，多少の悪天候 でも，河原でのキャンプを続けるケースが見られる，そん なとき，突然の雷雨で川が増水し，ダムにためていた水を 放流することがある。1999 年 8 月，神奈川県の玄倉川の 中州でキャンプをしていた 25 人に，危険だから避難する ようにと警告が伝えられたが 18 人はそれに従わなかった。 早朝，中州が水没し，消防による救助が試みられたが川の 流れが速く，救助は難航した，川の水位がさらに上昇し， 18 人が流され，13八が死亡する惨事が起きた。

かつて，都市河川は雨水を安全に速く海まで流す水路と して認識されていたが，水質污染で污れ，周辺住民からは 厄介者として扱われるようになってしまっていた。近年，

下水道の整備とともに，下水処理場の処理水を使った都市 河川の净化が行わ机るようになり，子どもたちが水辺で川 遊びができるような親水護岸や親水公園が都市近郊の河川 にできてきた。しかし，豪雨時には，都市河川は雨水が一 気に流れ出てくるため非常に危険な場所となる。2008 年 7 月，神戸市の都賀川の親水護岸で児童 18 人と引率者 3 人 が川遊びを楽しんでいるとき，雨が降ってきたので，一時 
橋の下で雨宿りしていた，雨が強くなり，危険を感じて川 から避難しようとしたそのときに，上流に降った豪雨が一 気に川に流れ込み，鉄砲水となって川を流れ下ってきた。 避難列の後乃にいた児童 2 人と引率者 1 人が濁流に押し流 され，児童 2 人が溺死した，別の場所でも園児と付き添い の女性が流され死亡した。東京でも同年 8 月，上流に降っ た局地豪雨が一気に下水道に流孔込み, 下水道の補修工事 をしていた 6 人が流され， 5 人が死亡する事故が起きた.

排水規模を超える豪雨が各地で降っており，山間地河川 や都市河川の川遊びの場所が突然危険になること, 地下室 の浸水，道路アンダパス部での車の水没など身近なところ で死亡事故が起こっていることに注意し，人身事故だけで も減らす努力が必要である。

\section{4. リアルタイムの浸水被害危険度予 測の取り組み}

繰り返し述べてきたように，排水規模を超える豪雨が各 地で降って抢り，低平な市街地が突然浸水することも想定 して扔く必要がある。㒵うした事態でも被害をできるだけ 軽隇できるように備えておくことが大切であり，その際， 時々刻々変化する浸水予測情報は有用な情報となる ${ }^{(3)(6)}$.

(独) 防災科学技術研究所では最先端の MP レーダ雨量情 報をリアルタイムに取得し，いつ，どこが，どの程度，浸 水して危険になるのかを 10 分ごとに, 1 時間先まで, $10 \mathrm{~m}$ 格子の高分解能で予測し，インターネットで情報提供する リアルタイム浸水危険度予測システムを開発し, 現在, 神 奈川県藤沢市南部などで害用化試験を行っている。このシ ステムは図 9 に示すように(1)雨量デー夕処理，(2)雨水流出 計算, (3)浸水被害危険度予測㧍よび(4)相互運用型 Web-GIS サーバからなっている。(1)は MP レーダ雨量情報をリアル タイムで取得し，10 分ごとに，河川流域は $50 \mathrm{~m}$ 格子，下 水道区域は計算 $10 \mathrm{~m}$ 格子の実況の雨量と 10 分ごとの 1 時 問先までの雨量情報を作成する。(2)は土地利用を考慮した 分布型タンクモデルを用いて，解析領域上流端の河川流量 と下水道網の主要なマンホール群への霜水流入量を計算す る. (3)では道路, 河川, 下水道管㸃, 堰, ポンプなどの構 造物を高速の水理計算ができるように単純化し，道路網と 下水道網を一体化した一次元ネットワークモデルを構築し た，水理計算にはりアルタイムの高速計算が可能で，国内 外で多くの使用実績があるデンマーク水理環境研究所の総 合都市下水道解析モデル（MOUSE）を用い，道路網㧍よ び下水道管渠網の任意の地点に扔ける浸水標高と流速を 10 分ごとに計算する。 また，道路上の推定浸水標高值と 流速值を用いて, 病院, 学校, 福祉施設など施設の被害発 生危険度扔よび歩いて避難する場合の危険度指標を計算す るとともに，それらを組み合わせた総合危険度のランクづ けを行う。(4)は計算した $10 \mathrm{~m}$ 格子の浸水深抢よび流速, 浸水被害総合危険度ランクのマップを作成し，インター ネットを通じて情報提供する。このサーバは利用者が持っ ている避難路地図や地域固有の防災マップを背景図とし て, その上に浸水深抢よび流速, 浸水被害総合危険度ラン クのマップを重ねて表示できる相互運用型 Web-GIS 機能 を持っている，また，計算結果を視覚的にわかりやすく見 せるため, Google Earthに重ねて,アニメーション表示で きる KML ファイルを作成守る機能も備えている. 現在, こ机らリアルタイムの浸水被害危険度情報を浸水想定箇所 の早期の安全対策や要援護者の早期避難に役立てる試みを 行っている.

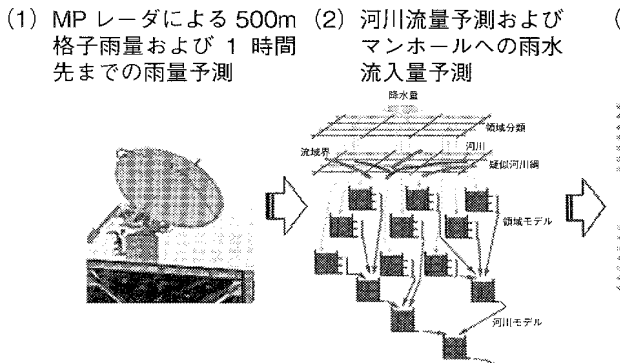

（3）道路網と下水道網を一 体化した浸水位計算お よび浸水危険度予測

（4）相互運用型の Web-GIS サーバ(あめリスク・ナウ)
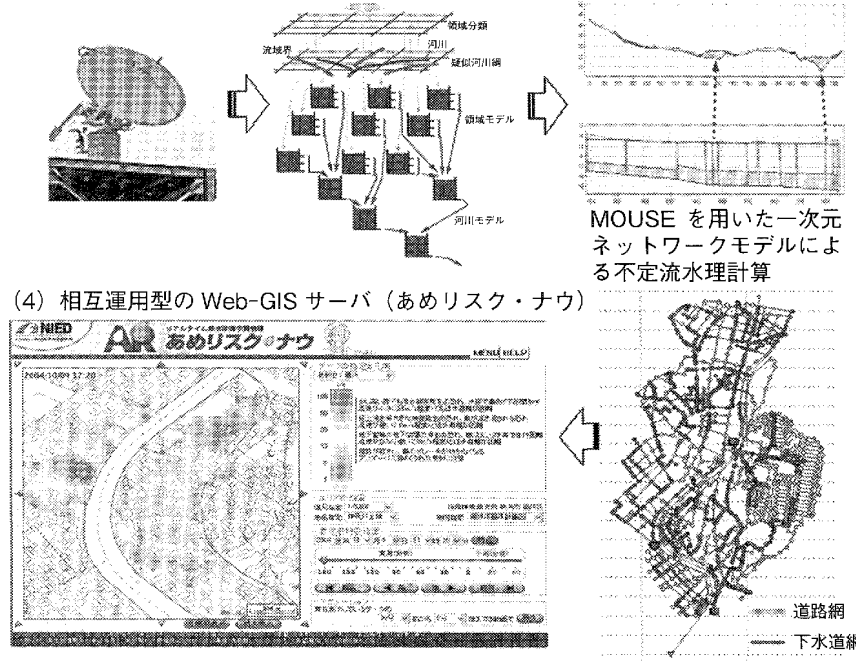
る不定流水理計算

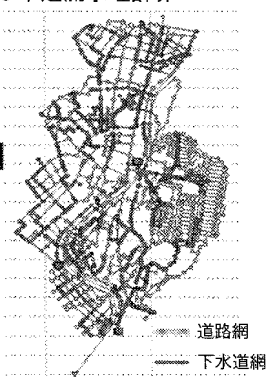

図 9 リアルタイム浸水被害危険度予測システムの概要

\section{5. まとめ}

時間雨量 $180 \mathrm{~mm}$ を超える豪雨が市街地に降るとどのよ うなことが起こるかを長崎豪雨災害の事例で述べた。毎年 のように都市下水道区域の排水能力を超える豪雨が降って 打り, 地下室の浸水や道路凹地の冠水が起こっている. 休 日の夜間に突然豪雨が降り, 日常の生活空間が同時多発的 に浸水して危険になることも想定される，兑のような場合 には浸水場所から自力で安全かつ迅速に避難することが必 要となる。そのための方法を具体的にイメージし，危険を 回避する知恵として身につけることが大切である。市町村 が公表する防災マップや洪水ハザードマップに関心を持 ち，それに自分なりの情報を加えて，周辺に潜む危険個所 を理解しておくことも必要である。また，気象予警報，雨 量・河川水位情報などさまざまな防災情報から自分に必要 な情報を選択取得して周辺で起こりそうな気像状況をイ メージすることが重要であり，そ扎によって日常モードか ら防災準備モードに切り替えられ，突然浸水に遭遇しても， 慌てることなく，危険を回避する知恵を働かすことができ ると思う。ここでは早期の避難を支援する詳細な浸水被害 危除度予測システムを紹介した。このような取り組みが地 域に広がり，地域から身近な周辺防災情報が出せる日が来 ることを期待している。

(2009 年 7 月 16 日)

文 献

（1）荒尾公雄, 気象, 長崎学術調査団昭和 57 年 7 月長崎豪雨によ る災害の調査報告書 (1982), 2-13.

（2）大八木規夫・中根和郎・福直輝旗，1982 年 7 月（57.9 豪雨）に よる長崎地区災害調査, 国立防災科学技術センター主要災害調 查第 21 号, (1984), 133.

（3）関根正人，集中豪雨に対して都市は本当に安全か?, 日本損害 保険協会予防時報，226（2006），8-13.

（4）高橋 博 - ほ力，豪雨・洪水防災，(1987），138-172，白亜書房.

（5）高橋和雄・高橋 裕, クルマ社会と水害一長崎豪雨災害は訴え るー, (1987), 182, 九州大学出版会.

（6）戸田圭一，短時間豪雨と都市水害，日本損害保険協会予防時報， 237 (2009), 22-27.

（7） 7.23 長崎大水害写真集, (1982)，128，長崎新聞社. 